\title{
ILMEISEN SIETÄMÄTÖN VETOVOIMA
}

Duncan J. Watts: Everything is Obvious - Once you know the Answer. How Common Sense Fails Us. Crown Business 2011.

Verkostoanalyysia on harrastatettu yhteiskuntatieteissä jo vuosikymmeniä, mutta suuren yleisön tietoisuuteen sosiaalisten verkostojen analyysi nousi vasta $2000-$ luvun alussa. Tämä kehityskulku johtui etenkin Internetin sosiaalisiin verkostoihin perustuvien sivustojen (social networking sites) suosiosta. Toisaalta asiaan vaikutti myös fyysikkojen ja matemaatikkojen kiinnostus verkostoanalyysia kohtaan ja se, että he alkoivat soveltaa verkostoanalyysia nimenomaan ihmisten välisten kytkösten selvittämiseen. Fyysikkojen ja matemaatikkojen versio verkostoanalyysista sai paljon huomoita puolipopulaarien teosten myötä, ja tämä suosio herätti närää monissa sosiologeissa, koska he kokivat, että fyysikot väittivät keksineensä sosiaalisten verkostojen analyysin, vaikka sitä oli tosiasiassa harrastettu yhteiskuntatieteissä jo iät ja ajat. Närkästyineisyys oli osittain täysin aiheellista, sillä verkostoanalyysin keinoinkin on osoitettu, että sosiaalisista verkoistoista kirjoittavat fyysikot eivät yleensä viittaa yhteiskuntatieteilijöiden kirjoituksiin. Tasapuolisuuden nimissä tosin on todettava, että yhteiskuntatieteilijät eivät ole tässä tapauksessa käyneet vieraissa yhtään sen aktiivisemmin.

Yksi verkostoanalyysia 2000-luvun alussa popularisoinneista teoksista oli Duncan J. Wattsin Six Degrees (2003). Teoksen nimi viittaa luonnollisestikin tunnettuun teesiin kuuden asteen yhteydestä, jonka mukaan täysin tuntemattomien ihmisten välillä vallitsee yllättävän lyhyitä "polkuja". Voidaan esimerkiksi ajatella, että jos haluaisin tavoittaa Yhdysvaltain presidentin tai vaikkapa täysin satunnaisen perähikiän mummon ihan mistä tahansa maasta, on- nistuisi tämä kyseisen teesin mukaan kuuden yhteyden kautta. Minun tarvisisi siis välittää viestini (mikä se ikinä sattuisikaan olemaan) kuuden ihmisen kautta tavoittaakseni Obaman tai kyseisen perähikiän mummon. Wattsin teos ei sortunut liialliseen yksinkertaistamiseen eikä se myöskään sivuuttanut sosiologista tutkimusperinnettä täysin. Siinä missä Wattsin edellinen kirja keskittyi nimenomaisesti verkostoanalyysin esittelyyn, on hänen uusimman kirjansa, Everything is Obvious - Once you know the Answer, teema laajempi, koska se käsittelee arkijärjen yleisiä ongelmia. Hänen oletuksensa on, että arkijärki on eräänlainen yleistaju, joka pohjautuu jokapäiväisten ongelmien kohtaamiseen arkielämässä. Arkijärkeä harvemmin puetaan eksplisiittisten ohjeiden muotoon, joten se on pikemminkin tavanmukaista ja intuitiivista toimintaa kuin tietoista päättelyä. Tästä syystä sitä on lähes mahdotonta opettaa tekoälylle ja roboteille. Wattsin oma tausta on kiinnostava, koska se kuvastaa monien verkostoanalyytikkojen monitieteellistä otetta: hän aloitti työuransa upseerina Australian armeijassa, väitteli mekaniikasta Yhdysvalloissa, toimi sosiologian professorina Columbian yliopistossa, kunnes päätyi nykyiseen toimeensa Yahoon!:n tutkimusyksikön johtajaksi (kyllä, Yahoo!-hakukonekin on edelleen olemassa - ja kyllä, se kirjoitetaan typerästi huutomerkillä).

Wattsin mukaan arkijärki toimii useimmiten hyvin ihmisten jokapäiväisessä elämässä, mutta ongelmiin törmätään välittömästi, jos arkijärkeä sovelletaan ongelmiin, jotka eivät ole jokapäiväisen ja käytännöllisen horisontin mukaisia. Yhteiskunnalliset ongelmat ovat Wattsin mielestä nimenomaan ongelmia, joihin arkijärkeä ei tulisi sotkea. Suomessakin on melko tavallista vaatia lisää "maalaisjärkeä", vaikka monesti juuri se - mikäli Wattsia on uskomi- 
nen - on alun perin johtanut meidät vaikeuksiin. Watts listaa kolmenlaisia teemoja, joissa arkijärkeen ei ole luottamista. Ensinnäkin yksilöiden käyttäytymisen selittämisessä on yleistä keskittyä tietoisiin motiiveihin, uskomuksiin ja insentiiveihin vaikka on ilmeistä, että tietoinen toiminta muodostaa vain jäävuoren huipun. Tähän tiedostamattoman toiminnan teemaan ovat monet muutkin teokset viime vuosina kiinnittäneet paljon huomiota, ${ }^{1}$ ja niinpä jätän sen käsittelyn vähemmälle arviossani.

Yhteiskuntatieteilijöiden kannalta kiinnostavampi ongelma on se, että kollektiivista toimintaa selitetään usein yksilötoiminnan logiikan kautta. Esimerkiksi "työläiset" tai"markkinat" tekevät arkiselityksissämme sitä tai tuota ilman, että pysähtyisimme hetkeksikään pohtimaan sitä, missä määrin kollektiiviset kokonaisuudet todella toimivat yksilöiden tavoin. Tällaisissa selityksissä nojataan implisiittisesti ajatukseen siitä, että työläiskollektiivin toimintaa voidaan ajatella jonkinlaisen keskivertotyöläisen toiminnan kautta; tämä keskivertotyöläinen siis edustaa koko joukkoa.

Watts ei kiistä, etteikö tällaista metaforista puhetta voisi harrastaa, mutta ongelmalliseksi se muodostuu, jos todella aletaan ajatella, että kollektiivit tekevät jotain samoin kuin yksilöt. Ei varmasti tarvitse avata kuin aamun sanomalehti löytääkseen selityksiä siitä, miten esimerkiksi markkinat reagoivat tähän tai tuohon asiaan ilman, että selitetään, mistä markkinoiden "reagoiminen" tarkkaan ottaen koostuu. Watts ei myöskään ole tyytyväinen selityksiin, joissa kollektiivista toimintaa selitetään jonkin ihmisryhmän kulttuurilla, koska niistä tulee helposti kehäpäätelmiä. Siis jokin ihmisryhmä toimii kuten toimii, koska heillä on tietynlainen kulttuuri - ja heillä on tämä kulttuuri, koska he toimivat niin kuin toimivat. Tämä ei tarkoita, että Watts edustaisi sellaista metodologista individualismia, jossa kiistettäisiin kollektiivisen tason emergenttien ominaisuuksien olemassaolo.

Watts havainnollistaa kulttuuriselitysten ongelmallisuutta viittaamalla sosiologi Mark
Granovetterin kuuluisaan ajatuskokeeseen, jossa selitetään mellakointia kollektiivisena ilmiönä. Ajatuskokeen pohjana on sosiaalipsykologinen havainto, jonka mukaan ihmiset ovat hyvin taipuvaisia omaksumaan ajattelu- ja käyttäytymismalleja muilta. Tässä omaksumisalttiudessa on kuitenkin yksilöiden välisiä eroja. Granovetter pyytää kuvittelemaan kaksi samankaltaista kaupunkia, joista toisessa osoitetaan mieltä rauhanomaisesti, kun taas toisessa mielenosoitus kiihtyy mellakaksi asti. Perinteinen sosiologinen selitys saattaisi viitata esimerkiksi siihen, että vain toisessa näistä kaupungeista sattuu olemaan erityinen mellakoinnin kulttuuri. Kenties siellä on mellakoitu ennenkin, mikä vahvistaa kulttuuriin viittavaa johtopäätöstämme. Voidaan kuitenkin ajatella, että ihmisillä on erilaisia kynnyksiä osallistua mellakointiin. Mellakoimisen omaksumiskynnys viittaa tässä siihen, kuinka monen henkilön täytyy mellakoida, jotta itse kukin lopulta osallistuu.

Granovetterin kuvitteellisessa esimerkissä toisen kaupungin populaation mellakoinnin omaksumiskynnykset ovat jakautuneet juuri sopivasti niin, että lopulta kaikki osallistuvat. Ensinnäkin yhdellä ihmisellä kynnys on nolla, joten hän ryhtyy syystä tai toisesta mellakoimaan omatoimisesti. Sitten löydämme henkilön, jonka kynnys on yksi, joten hän osallistuu toimintaan, kun yksi henkilö on alkanut heitellä kiviä ynnä tehdä muuta sellaista, jota lehdistö tuppaa nimittämään rähinöinniksi. Omaksumiskynnys "yksi" tarkoittaa tässä siis sitä, että sosiaalisesta verkostosta (mielenosoittajien populaatio) yhden on täytynyt omaksua käyttäytymismalli, jotta tämä ykköskynnyksen omaava henkilö myös omaksuu kyseisen mallin. Seuraavalla mielenosoittajalla kynnys on kaksi, joten pian hänkin liittyy iloiseen joukkoon. Sovitaan, että populaation koko on 100 henkilöä ja jos omaksumiskynnykset ovat jakautuneet sopivasti yhdestä sataan, niin lopulta kaikki osallistuvat mellakointiin. Toisessa kaupungissa kynnykset ovat jakautuneet melkein samoin, mutta välistä puuttuu henkilö, jonka omaksumiskynnys on viisi. Tällöin prosessi alkaa tismalleen 
samoin: yksi mellakoi, toinen liittyy joukkoon ja niin edelleen kunnes viisi henkilöä viskelee kiviä poliisia kohti, mutta koska kellään ei ole omaksumiskynnystä viisi, lopahtaa prosessi pian kasaan. Paikalta kyllä löytyy mielenosoittaja, jonka omaksumiskynnys on kuusi, mielenosoittaja, jolla se on seitsemän ja niin edelleen, mutta näiden henkilöiden osallistuminen mellakointiin olisi edellyttänyt kuuden henkilön jo mellakoivan - mitä ei tapahdu viitoskynnyksen omaavan mielenosoittajan puuttumisen takia.

Granovetterin kuvitteellisen esimerkin kärki kohdistuu siihen, että viittaaminen sen paremmin eroihin mellakoinnin kulttuurissa kuin eroihin edustavissa yksilöissä ("mielenosoittajat sitä tai tätä") olisi harhaanjohtavaa, sillä asiaa selittävät verkostolliset tekijät - tietynlaisten omaksumiskynnysten omaavien henkilöiden välinen vuorovaikutus. Kirjassa pohditaan paljon yksilö- ja populaatiotason välisiä suhteita. Wattsin mukaan on yleisesti ottaen niin, että hyvinkin pienet vaihtelut ja muutokset yksilöiden toiminnassa voivat saada aikaan suuria populaatiotason vaikutuksia kumulatiivisena hyötynä tunnetun prosessin myötä. Esimerkiksi jostain kirjasta saattaa tulla suosittu sitä kautta, että ihmiset pitävät sitä suosittuna ja päättelevät tämän suosion heijastavan sitä, että kirjan täytyy olla itsessään hyvä. Näin alun perin muita hieman suositummasta kirjasta voi tulla entistä suositumpi muiden kirjojen jäädessä entistä vähemmälle huomiolle. Asioiden suosiosta on siis arkijärjessä tapana päätellä jotain asioiden sisäisistä attribuuteista. Miljoona kärpästä ei voi olla väärässä!

Watts on kollegoidensa kanssa havainnollistanut tätä efektiä virtuaalisella kokeella, jossa testattiin musiikkikappaleiden suosioon vaikuttavia tekijöitä. Kokeen osallistujat käyttivät nettisivustoa, jossa heille näytettiin listaus siitä, mitkä artistit ja kappaleet ovat suosittuja kunakin hetkenä. Osallistujat jaettiin kuitenkin hieman eri ryhmiin niin, että suosittujen kappaleiden lista näytti kussakin ryhmässä aluksi erilaiselta, mutta kokeen kuluessa listaus heijasti reaaliaikaisesti ladattujen kappaleiden suosiota.
Ihan mistä tahansa kappaleesta ei tullut suosittua tai myöskään pahnan pohjimmaista, joten kappaleilla itselläänkin oli vaikutusta menestykseen. Yleisesti ottaen kuitenkin erot alkuasetelmassa - se minkä kappaleiden väitettiin olevan suosittuja - vaikutti vahvasti lopputulokseen: suosituiksi listatuista kappaleista, jotka siis vaihtelivat eri ryhmissä, tuli lopulta entistä suositumpia. Periaatteessa lähes mikä tahansa lopputulema oli mahdollinen sen perusteella, minkä väitettiin olevan suosittua. Tässä tuloksessa riittää pohdittavaa levy-yhtiöiden tuottajille, mutta Wattsin mukaan samankaltainen kumulatiivisen hyödyn prosessi voi selittää monia sosiaalisia ilmiöitä laajemminkin. Onkin helppo nähdä, että vastaava prosessi, jota on joskus kutsuttu Matteus-efektiksi, voi olla esimerkiksi koulujen ja asuinalueiden segregaation taustalla. Suositun koulun täytyy olla hyvä, kun taas vähemmän suositussa koulussa täytyy olla jotain vikaa - ja kohta näin voi todella ollakin, kun sekä keskimääräistä hieman parempien oppilaiden että opettajien keskittyminen tiettyihin kouluihin todenteolla alkaa suosioon perustuvien mielikuvien pohjalta.

Kirjassa käsitellään suhteellisen vähän varsinaista sosiaalisten verkostojen teoriaa ja tutkimusta, mutta Watts kiinnittää huomiota verkostotutkimuksen kysymykseen siitä, onko jonkin asian leviämisessä tärkeintä se, että populaatiossa on erityisyksilöitä, joille on kasautunut paljon sosiaalisia yhteyksiä vai se, että verkoston "noodit" (eli ihmiset) sattuvat olemaan vaikutusalttiita. Populaarissa tiedejulkisuudessa etenkin Malcolm Gladwell on korostanut erityisyksilöiden tärkeyttä sosiaalisten epidemioiden leviämisessä2 ${ }^{2}$ Sosiaalinen epidemia voi olla esimerkiksi jonkin uuden kaupallisen tuotteen leviäminen johonkin populaatioon. Perinteinen innovaatioiden leviämisen tutkimus on alleviivannut sitä, että niin sanotuissa silta-asemissa olevat yksilöt, joilla on sosiaalisia linkkejä tiiviiden klikkien ulkopuolelle, ovat alttiimpia omaksumaan ja levittämään uusia ajattelumalleja ja käytäntöjä. Gladwellin mukaan esimerkiksi kuuden asteen yhteyttä käsittelevä niin sa- 
nottu pieni maailma -havainto on mahdollinen siksi, että populaatioissa on aina henkilöitä,joille sosiaaliset yhteydet kasautuvat. He yhdistävät monia toimijoita toisiinsa epäsuorasti ja ovat näin ollen myös innovatiivisten kulttuuristen käytäntöjen lähteitä. Watts ei käsittele asiaa tarkemmin, mutta näille innovaattoreille voidaan löytää myös yhteisiä taustamuuttujia, kuten se, että he ovat kosmopoliittisesti asennoituneita, seuravaat paljon mediaa ja heidän sosioekonominen asemansa on hieman korkeampi kuin tavallisten pulliaisten.

Sosioekonominen asema ei voi kuitenkaan olla liian korkea suhteessa niihin henkilöihin, joihin he ovat yhteydessä, sillä muutoin he erottautuisivat liiaksi joukosta ollakseen uskottavia uusien käytäntöjen lähteitä. Kuten verkostotutkijat ovat pitkään korostaneet, sosiaalisen elämän keskeinen periaate on homofilia eli se, että samankaltainen seura viehättää meitä - ja myös tekee meistä entistä samankaltaisempia. Sivu mennen sanoen, sosiologiassa usein kuvitellaan, että nimenomaan media toimii uutisoinnin ja mainosten kautta esimerkiksi uusien diskurssien omaksumisen lähteenä. Näin varmasti onkin - mutta lähinnä vain innovaattorien osalta. Me tavalliset pulliaiset saatamme kyllä tulla median kautta tietoiseksi jostain diskurssista tai muusta vastaavasta, mutta tarvitsemme ensin vahvistusta henkilökohtaiselta sosiaaliselta verkostoltamme ennen kuin todella vakuutumme siitä, että kyseisen diskurssi kannattaa omaksua. Innovaattori omaksuu siis ensin - jos omaksuu - ja mattimeikäläiset seuraavat perässä, jos ovat kytköksissä innovaattoriin. Watts kuitenkin osoittaa simulaatiotutkimuksen avulla, että yleisestikin epidemioiden leviäminen riippuu vähintään yhtä paljon siitä, että populaatiossa on omaksumisalttiita yksilöitä. Hänen mukaansa on niin, että jos omaksumisalttiiden henkilöiden määrä jää liian alhaiseksi, kriittistä massaa ei ikinä tulla ylittämään vaikka populaatiossa olisikin paljon henkilöitä, joille verkostoyhteydet ovat kasautuneet.

Käytännön johtopäätös tästä keskustelusta on se, että arkijärkeen nojaamalla kuvittelem- me liian helposti jonkun "erityisyksilön" olevan esimerkiksi onnistuneiden kaupallisten innovaatioiden lähteenä. Applen Steve Jobs on ehditty julistaa monissa muistokirjoituksissa neroksi, mutta Applen menestyksen takana olivat todennäköisesti monet satunnaiset, muun muassa toisiinsa kytköksissä olleiden ihmisten omaksumisalttiuteen liittyvät tekijät, joihin Jobsilla ei ollut osaa eikä arpaa. Watts vetää asiasta myös yhteiskuntapoliittisia johtopäätöksiä: yritysten johdon palkitseminen ylettömillä bonuksilla on järjetöntä, lähes karismaattisen messiaan etsimiseen verrattavissa olevaa puuhaa, sillä yritysten tulos riippuu monista seikoista, joihin toimitusjohtaja ei taatusti ole vaikuttanut eikä välttämättä edes voi vaikuttaa. Wattsin innovaatioiden leviämistä koskeva kritiikki olisi vahvemmalla pohjalla, jos hän erittelisi enemmän innovaatioiden leviämistä koskevia empiirisiä tutkimustuloksia. Nyt nämä yritetään kumota yhden simulaatiotutkumuksen avulla ilman, että niitä edes kunnolla käsitellään.

Kolmannen arkijärjen ongelmakokonaisuuden muodostavat historialliset selitykset, joissa painotetaan liikaa sitä, mitä kulloinkin sattui tapahtumaan sen kustannuksella, mitä olisi voinut tapahtua. Wattsin kirjan nimi viittaa tähän ongelmaan; kaikki näyttää usein ilmeiseltä - kun tiedämme, mitä myöhemmin tapahtui. Esimerkiksi tänä päivänä saattaa näyttää siltä, että Applen tietokoneet ja puhelimet ovat ilmiselvästi parempia kuin kilpailijoiden tuotteet eikä siis ole mikään ihme, että Applen pörssiarvo hakkaa Nokian mennen tullen. Mutta kuinka moni olisi osannut ennustaa tämän lopputuloksen etukäteen? Eikä se edes ole mikään lopullinen "lopputulos", sillä on osin mielivaltaista valita juuri tämä hetki arviointipisteeksi. Apple nojasi strategiassaan moniin elementteihin, jotka olisivat hyvinkin voineet epäonnistua, koska tiedämme, että vastaavat strategiat ovat aiemmin epäonnistuneet. Mutta kun tiedämme, että Applen tuotteet ovat menestyneitä, niiden menestys näyttää väistämättömältä.

Mitään kunnollista keinoa historiallisten selitysten arvioimiseksi ei Wattsin mukaan ole 
olemassa, koska historia tunnetusti tapahtuu vain kerran. Emme siis voi järjestää historiallista koeasetelmaa, jossa varioitaisiin tiettyä muuttujaa ja katsottaisiin, miten se vaikuttaa lopputulokseen. Toki historiallisista tapahtumista voidaan kerätä tilastoja pidemmältä aikaväliltä ja päätellä esimerkiksi, että talouden kehitys noudattaa tiettyjä syklejä tai että kansanmurhat eivät ole todennäköisiä demokraattisissa valtioissa. Wattsin mukaan kuitenkin kaikista kiinnostavimmat historialliset tapahtumat - kuten sodat, taloudelliset romahdukset ja niin edelleen - ovat niin uniikkeja, ettei niiden todennäköisyyksiä oikeasti voi päätellä tilastoista. Ja vaikka kuinka yrittäisimme, kiinnitämme aina liikaa huomiota siihen, mitä todella tapahtui sen kustannuksella, mitä olisi voinut tapahtua. Kieltämättä onkin hämmästyttävää, millaisella varmuudella sanomalehtien pääkirjoitusten laatijat ja mediassa haastatellut asiantuntijat kertovat esimerkiksi vaalien jälkeen, mistä syistä tämän tai tuon puolueen menestys tai tappio johtui. Ainakin asiantuntijoiden luulisi tietävän, että korrelaatio ei välttämättä tarkoita kausaalisuhdetta. Kun korrelaatio ja kausaatio samaistetaan jälkikäteisviisaasti, on Wattsin mukaan kyse post hoc -virhepäätelmästä.

Historiallisessa selittämisessä nojataan jälkikäteisviisauteen käyttämällä narratiivisia lauseita, jotka "oletettavasti kuvailevat jotain tietyn hetken tapahtumaa, mutta tekevät sen niin, että ne edellyttävät tietoa myöhemmästä hetkestä” (s. 124). Tällaiset narratiiviset lauseet ovat kuitenkin välttämättömiä historialliselle selittämiselle eikä Watts vaadi, että niistä pitäisi päästä eroon. Lienee kuitenkin hyvä olla tietoinen siitä, että narratiiviset lauseet eivät vain kuvaile jotain tiettyä tapahtumaa, vaan arvioivat asioita tiedetystä lopputuloksesta käsin. Watts myös toivoisi lisää kontrafaktuaalista historiankirjoitusta, joka kiinnittäisi enemmän huomiota ei-ilmeiseen eli siihen, mitä olisi voinut tapahtua, mutta ei tapahtunut. Ongelmansa on siinäkin, että arkijärki kirjoittaa historiaa niin, että moninaiset ja hyvinkin pitkäkestoiset tapahtumaketjut pelkistetään jonkin yksittäisen nimikkeen alle (esimerkiksi "toinen maailmansota").

Jos historiallinen selittäminen on ongelmallista, niin tulevaisuuden ennustaminenpa se vasta onkin veemäistä puuhaa! Taloustietelijöitä ja tulevaisuudentutkijoita lukuunottamatta harva yhteiskuntatieteilijä pitää ennustamista hyvän teorian keskeisenä kriteerinä, joten siinä mielessä Wattsin ennustamisen ongelmia erittelevä osuus on saarnaamista kääntyneille; ennustaminen on niin vaikeaa, että suurin osa yhteiskuntatietelijöistä ei edes uskalla yrittää. Toisaalta asialla on suuri merkitys yhteiskuntapolitiikan kannalta, sillä se nojaa jatkuvasti erilaisiin ennusteisiin esimerkiksi työikäisen väestön ja vaikkapa talouden kehityksestä. Watts viittaa Philip Tetlockin tekemään kiinnostavaan tutkimukseen, jossa pyydettiin vajaalta 300 asiantuntijalta ennusteita erilaisista yhteiskunnallisista kehityskuluista (muun muassa vaalien tuloksista ja aseellisten konfliktien todennäköisyyksistä). Vastaukset saatuaan Tetlock odotti 20 vuotta ja katsoi, miten hyvin ennusteet pitivät paikkansa. Kuten lukija saattaa tässä vaiheessa jo arvata, asiantuntijat pärjäsivät hyvin huonosti; heidän ennusteensa olivat hieman parempia kuin satunnaisesti arpomalla saadut vastaukset, mutta yksinkertainen tilastollinen malli pärjäsi asiantuntijoita paljon paremmin. (Kiinnostava lisähavainto oli se, että asiantuntijoiden ennusteet olivat yleensä osuvampia heidän varsinaisen eskpertiisialueensa ulkopuolelle sijoittuvissa kysymyksissä.) Wattsin mukaan yhteiskunnallisten tapahtumien ennustamisessa ei kannata missään nimessä nojata ainakaan yhden tai muutaman asiantuntijan arvioon - eli ei pitäisi toimia niin kuin sanomalehdet tekevät haastattelemalla paria ekonomistia tulevasta talouskehityksestä.

Ennustamisen ongelmien päälähteeksi Watts paikantaa sosiaalisen maailman ilmiöiden monimutkaisuuden. Yksinkertaisten systeemien kohdalla voimme olla epävarmoja tulevaisuudesta, mutta sellaisten monimutkaisten järjestelmien kuin talousjärjestelmän suhteen kyse ei ole informaation puutteesta, vaan sii- 
tä, että emme edes periaatteessa voi ennustaa tulevaa. Wattsin mukaan näyttää paradoksaalisesti siltä, että monimutkaisten järjestelmien tapahtumia ennakoitaessa melko yksinkertaiset mallit toimivat parhaiten. Monimutkaisten järjestelmien kohdalla muuttujien lisääminen ja mallin monimutkaistaminen ei siis tee mallista yhtään sen tarkempaa. Watts ei käy keskustelua taloustieteen mallien luonteesta, mutta niitähän usein kritisoidaan juuri siitä, että ne ovat liian yksinkertaisia ja epärealisisia. Taloustieteen mallien puolustukseksi voisi Wattsin kirjan pohjalta sanoa, että talous on monimutkainen järjestelmä ja näin ollen sen tapahtumien ennustamisessa nimenomaan yksinkertainen malli voi olla paras. Tällöin tulee kuitenkin pitää mielessä, että malli tosiaankin on täysin epärealistinen eikä sen käsitystä esimerkiksi rationaalisuudesta tule missään mielessä pitää todenmukaisena. Lisäksi parhaatkin mallit ovat monimutkaisten järjestelmien tapauksessa väistämättä aina hyvin erehtyväisiä.

Wattsin mukaan ennustamisessa ja tulevaisuuskenaarioiden maalaamisessa ei myöskään tulisi pidättäytyä pelkissä jäykissä malleissa. Tähän internet tarjoaa hänen mukaansa toimivan lääkkeen. Esimerkiksi influenssaepidemioiden esiintyvyyttä on Yhdysvalloissa ennustettu influenssaan liittyvien Google-hakujen perusteella. Tällainen ennustaminen on luonnollisestikin hyvin reaaliaikaista, mutta Wattsin mukaan monimutkaisten järjestelmien tapahtumien ennustamisessa pitäisikin pyrkiä esimerkiksi tällaiseen reaaliaikaiseen "kollektiivitietoisuuden" seurantaan ja reagointiin sen muutosten myötä, sillä muutoin osutaan melko varmasti harhaan. Ei ole kovin yllättävää, että Watts korostaa internet-pohjaisten aineistojen kiinnostavuutta - onhan hän nimenomaan Yahoon!:n leivissä. Watts menee jopa niin pitkälle, että näkee internetin mahdollistamissa jättiaineistoissa (esim. miljoonien ihmisten matkapuhelinyhteydet) tieteellisen vallankumouksen siemenen. Tieteelliset vallankumoukset ovat hänen mukaansa tapahtuneet luonnontieteissä usein niin, että puuhun mennään instrumentit edellä (esim. kaukoputken keksiminen) ja jotain samantapaista voisi oletettavasti siis tapahtua nyt, kun voimme ensimmäistä kertaa mitata muun muassa ihmisten välisiä yhteyksiä laajassa mittakaavassa. Kieltämättä internetin niin sanottu big data avaa kiinnostavia mahdollisuuksia yhteiskuntatietelijöille ja myös humanisteille. Esimerkiksi Google Booksin miljoonien kirjojen käyttäminen kvantitatiivisen analyysin aineistona tuskin korvaa kirjojen lähilukua, mutta se mahdollistaa sellaisten analyysien tekemisen, jotka eivät onnistu pelkkien ihmislukijoiden voimin ${ }^{3}$.

Watts ei halua harrastaa pelkästään ylhäältä alaspäin suuntautuvaa sosiaali-insiröintiä. Tämä näkyy siinä, että vaikka hän korostaa pelkkään arkijärkeen nojaamisen ongelmallisuutta, painotetaan kirjassa samanaikaisesti paikallisen tiedon tärkeyttä. James Sott ja Friedrich Hayek paiskaavat kirjassa iloisesti kättä, kun tarkoituksena on sen alleviivaaminen, että yhteiskunnallisen suunnittelun tulisi aggregoida lokaali tieto. Kuten tunnettua, Hayekin mukaan markkinamekanismi on esimerkki sellaisesta lokaalin tiedon aggregoinnista, joka ei tarvitse keskussuunnittelijaa asettamaan ennalta esimerkiksi tuotantotavoitteita. Watts kuitenkin toppuuttelee markkinauskoisia, sillä markkinoiden lisäksi on olemassa myös monia muita tapoja hyödyntää lokaalia tietoa. Näiden muiden tapojen osalta Wattsin kirjalla ei ole mitään kovin syvällistä sanottavaa. Hän mainitsee muun muassa niin sanotut palkintokilpailut (prize competitions), joissa esimerkiksi julkinen valta asettaa tietyn poliittisen päämäärän, kilpailuttaa parhaat keinot sen saavuttamiseksi ja palkitsee parhaan ehdotuksen. Tässä esimerkissä valtio ei siis päätä jokaista yksityiskohtaa, vaan jättää kilpailuun osallistujien päätettäväksi, miten tavoitteeseen päästään (eikä myöskään maksa hävinneiden suunnitelmien tekijöille palkkioita). Tällainen menettely saattaa säästää valtion verorahoja ja voi sopia hyvin esimerkiksi teknisiin hankkeisiin. On kuitenkin vaikea kuvitella, että siitä olisi ainesta yhteiskuntapolitiikan yleiseksi ohjenuoraksi. 
Wattsin kirja on sosiologisen yleissivistyksen osalta paikoin hieman ohut. Esimerkiksi valta-teemaa ei käsitellä eksplisiittisesti lainkaan, vaikka se on aihe, johon verkostotutkijat ovat monesti paneutuneet. Kirjaa voisi epäilemättä silti käyttää pääsykoe- tai kurssikirjana, koska siinä käsitellään monia sellaisia kysymyksiä, joita jokainen yhteiskuntatietelijä joutuu työssään pohtimaan. Muidenkin kuin opiskelijoiden kannattaa perehtyä teokseen ennen kaikkea siksi, että sosiologit ja yhteiskuntatieteilijät tulevat selvästikin jälkijunassa big datan ja nettiaineistojen mahdollisuuksien hyödyntymisessä. Vaikka Watts onkin turhan naiivin optimistinen sen suhteen, millaisen tieteellisen vallankumouksen big data voi saada aikaan, ei voi kiistää, etteikö sen mahdollisuuksia kannattaisi hyödyntää yhteiskuntatieteissä nykyistä huomattavasti enemmän. Wattsin tutkimusote näyttää myös, että vuoropuhelu käyttäytymistieteiden kanssa on mahdollista ilman, että tarvitsee pelätä minkäänlaista reduktionismia. Humanistisilla, "ymmärtävää" tutkimusotetta korostavilla opeilla kyllästetyt tutkijat saattavat silti säikähtää kirjan käsitystä yhteiskuntatieteistä, jossa selvästi painottuu selittävä tutkimusote. Epäilemättä jopa positivismi-leimasin saatetaan joissain piireissä kaivaa naftaliinista. Sille ei kuitenkaan voi mitään, että selittävät tutkimusasetelmat ovat tarpeen, jos haluamme tehdä yhteiskuntapoliittisesti relevanttia tutkimusta. Lisäksi Watts on itse ensimmäisenä myöntämässä, että joidenkin fyysikkojen fantasiat yhteiskuntatieteiden muuttamisesta fysiikan kaltaiseksi eksaktiksi tieteeksi ovat harhakuvitelmia, sillä"sosiaalinen maailma [...] on paljon sotkuisempi kuin fysikaalinen maailma ja mitä enemmän opimme sosiaalisesta maailmasta, sitä sotkuisemmalta se vaikuttaa" (s. 262).

Voisin kuvitella, että historioitsijat saattavat pitää kirjan historiallista selittämistä koskevaa osiota itsestäänselvyyksien (sic!) luettelemisena. Ei-historioitsijalle se kuitenkin toimii hyvänä muistutuksena siitä, että arkiselitykset usein unohtavat historiallisten selitysten hankaluu- den. Toisaalta Watts olisi voinut reflektoida enemmän tätä teemaa kontrafaktuaalisen ja etenkin vertailevan historiankirjoituksen mahdollisuuksia vasten. Joidenkin mielestä nämä menetelmät nimittäin mahdollistavat juuri sellaiset koeasetelmat, joiden rakentamista Watts pitää historiallisessa selittämisessä mahdottomana.

Kirjan suurimpia puutteita lienee kuitenkin se, että siinä ei pohdita arkijärjen mahdollista vaikutusta sosiaaliseen todellisuuteen. Anthony Giddens on käyttänyt käsitettä kaksoishermeneutiikka ja Ian Hacking on vuorostaan puhunut muun muassa interaktiivisista luokista. Molemmat käsitteet viittavaat sosiaalista maailmaa kuvaavien käsitysten ja sosiaalisen maailman väliseen vuorovaikutussuhteeseen tai takaisinkytkentään. Sanotaan, että pidämme esimerkiksi työttömyyttä ihmisten omana syynä, vaikka näin ei todellisuudessa olisikaan. Tällä käsityksellä voi olla vaikutusta itse työttömiin, jos he todella alkavat pitää työttömyyttä omana syynään. Näin sosiaalinen todellisuus osittain mukautuu (virheellisen) käsityksemme mukaiseksi. Toisaalta voi käydä niinkin, että työttömät ryhtyvät vaikkapa yhdistystensä kautta vastustamaan tätä leimaavaa käsitystä työttömyyden syistä, mikä voi puolestaan muuttaa meidän käsitystämme työttömistä - ja tämä muuttunut käsitys voi edelleen vaikuttaa työttömiin ja niin edelleen. Arkijärki on siten monimutkaisessa vuorovaikutussuhteessa sosiaaliseen todellisuuden kanssa. Toisaalta voisi todeta, että juuri tästä syystä Wattsin kirjan sanomalla on painoarvoa; arkijärjen käsityksillä todella on merkitystä.

- ANTTI GRONOW

VIITTEET

1. Ks. esim. Daniel Kahneman (2011): Thinking Fast and Slow. Allen Lane.

2. Malcolm Gladwell (2000): The Tipping Point. How Little Things Can Make a Big Difference. Abacus.

3. Jean-Baptiste Michel ym. (2011): Quantitative Analysis of Culture Using Millions of Digitalized Books. Science 331, 176-183. 